Levinson, G., Guzmán-Toledano, R., Canales, E. S., and Zárate, A (1975). Sindrome de agonadismo o agenesia gonadal en una paciente con pseudohermafroditismo y cariotipo 46,XY. Revista de Investigación Clinica, 27, 231-237.

Overzier, C. and Linden, H (1956). Echter Agonadismus (Anorchismus) bei Geschwistern. Gynaecologia, 142, 215-233.

Philipp, E. (1956). Die Fehlbildungen der Keimdrüse. Deutsche medizinische Wochenschrift, 81, 1298-1302.

Sarto, E. G. and Opitz, M. J. (1973). The XY gonadal agenesis syndrome. Fournal of Medical Genetics, 10, 288-293.

Siler, T. M. and Yen, S. S. C. (1973). Augmented gonadotropin response to synthetic LRF in hypogonadal state. Fournal of Clinical Endocrinology and Metabolism, 37, 491-494.

Zárate, A., Canales, E. S., De la Cruz, A., Soria, J., and Schally, A. V. (1973). Pituitary response to synthetic LH-RH in SteinLeventhal syndrome and functional amenorrhea. Obstetrics and Gynecology, 41, 803-808.

\section{Further observations on the Birmingham chimaera}

Summary. The appropriate ABHgene specified glycosyltransferases in the plasma of the Birmingham chimaera were estimated. These observations and the demonstration of $\mathrm{A}_{1} \mathrm{Le}^{\mathrm{b}}$ blood group specific glycosphingolipid in the plasma indicate that the minority population of red blood cells probably represents the true blood groups of the patient.

We recently reported (Battey et al, 1974) a human female chimaera with two red cell populations and an overwhelming preponderance of lymphocytes which were of the normal male karyotype $46, X Y$. We have further investigated this patient in the light of new knowledge.

\section{Case report}

\section{Blood group gene products in plasma}

The patient has a mixture of about $93 \% \mathrm{O}$ and $7 \% \mathrm{~A}_{1}$ red cells. We, therefore, investigated the patient's plasma for $A$ - and $H$-gene specified transferases, with the undermentioned results:

$\alpha-\mathrm{N}$-acetylgalactosaminyltransferase

(the primary product of the blood group A

gene) activity at $p \mathrm{H} 6$

$\alpha-2$ '-fucosyltransferase

(the primary product of the blood group

$\mathrm{H}$ gene) activity at $p \mathrm{H} 7.2$

The percentages represent the amount of radioactivity transferred to a low molecular weight acceptor from UDP- $\left[{ }^{14} \mathrm{C}\right]-\mathrm{N}$-acetylgalactosamine and GPD- $\left[{ }^{14} \mathrm{C}\right]-$ fucose. A normal $A_{1}$ control plasma gave $29 \%$ incorporation when tested under the same conditions with UDP- $\left[{ }^{14} \mathrm{C}\right]-\mathrm{N}$-acetylgalactosamine. The $2^{\prime}$-fucosyltransferase activity fell within the range expected for an $A_{1}$, and was rather high for an $O$ donor. A few $O$ sera do have activities as high as the figure given above; we find, however, that the average for $A$ donors is higher than for $\mathrm{O}$ or $\mathrm{B}$ donors (M. A. Chester and W.M. Watkins, unpublished observations). It can; therefore, be claimed that the patient behaves, as far as her transferases are concerned, like a normal $A_{1}$ person.

\section{$A_{1} L^{b}$ blood group specific substance}

The hybrid $A_{1} L^{b}$ blood group specific substance is a glycosphingolipid present in the plasma of a person who has inherited the $A_{1}, L e, H$, and $S e$ genes (Swanson et al, 1971; Tilley et al, 1975). The $\mathrm{A}_{1} \mathrm{Le}^{\mathrm{b}}$ substance coats red cells in the same way as ordinary $\mathrm{Le}^{\mathrm{a}}$ and $\mathrm{Le}^{\mathrm{b}}$ substances.

Red cells coated with $A_{1} L^{b}$ are agglutinated by an antibody anti- $\mathrm{A}_{1} \mathrm{Le}^{\mathrm{b}}$ which does not agglutinate cells coated with either $\mathrm{A}_{1}$ or $\mathrm{Le}^{\mathrm{b}}$ alone (Seaman, Chalmers, and Franks, 1968; Crookston, Tilley, and Crookston, 1970; Gundolf, 1973).

In twin or bone-marrow transplantation chimaeras, $\mathrm{A}_{1} \mathrm{Le}^{\mathrm{b}}$ substance coats the subject's true red cells as well as those derived from grafted bone-marrow (Crookston et al, 1970; Swanson et al, 1971; Wrobel et al, 1974).

The red blood cells of our patient were tested with an anti- $A_{1} L e^{b}$ serum kindly provided, through $\mathrm{Dr} K$. L. G. Goldsmith, by Dr Carolyn Giles, who had obtained it from Mrs Marie Crookston. All the red cells were agglutinated by this reagent; this showed that her $\mathrm{O}$ red cell population was also 'stamped' with her true genetic marker, $\mathrm{A}_{1} \mathrm{Le}^{\mathrm{b}}$. Tests with a potent anti-A also showed that her $\mathrm{O}$ cells were coated with $\mathrm{A}$-substance.

\section{Discussion}

Although our patient was said not to be a twin, her twin may have been aborted or assimilated. We were unable to obtain firm evidence that dispermy was responsible. If she is really a twin (and we suspect she is), the true blood groups of our patient are those represented by her minority red cell population, as indeed her true sex is that represented by her minority lymphocyte population $(46, \mathrm{XX})$. Similar observations have been made by Wrobel et al (1974). The presence of normal amounts of $A$-gene transferase and of $\mathrm{A}_{1} \mathrm{Le}^{\mathrm{b}}$ blood group specific substance in our patient's plasma does not necessarily indicate that she is really a twin. A final opinion must await the results of similar studies in dispermic chimaeras. If she is really a dispermic chimaera, she would of course have two 'true' red cell populations.

In our patient and in other chimaeras, there is much disproportion between the relatively small numbers of red cells which constitute the minority population and the normal levels of the corresponding serum transferase. It is, therefore, highly likely that a large proportion of the $A B H-b l o o d$ group gene specified transferases in plasma are derived from sources other than the bone-marrow. 
Furthermore, it is also obvious, from the presence of a population of circulating red cells (group $\mathrm{O}$ in our patient) which are not modified by transferase present in plasma (A-transferase in our patient), that the final step in the formation of $\mathrm{ABH}$-active sites on the red cell surface does not occur in the external environment of the cells (Race and Watkins, 1972), and is therefore mediated in the bone-marrow by a process yet to be elucidated.

We gratefully acknowledge the keen interest and valuable advice of Dr Ruth Sanger and Mrs Marie Crookston.

G. W. G. Bird, Diana A. Battey, Pamela Greenwell, C. W. Mortimer, WINIFRED M. WATKINS, and JUNE WINGHAM

Regional Blood Transfusion Service, Birmingham; the Good Hope Hospital, Sutton Coldfield; and the Lister Institute of Preventive Medicine, London

REFERENCES

Battey, D. A., Bird, G. W. G., McDermott, A., Mortimer, C. W., Mutchinick, O. M., and Wingham, J. (1974). Another human chimaera. Fournal of Medical Genetics, 11, 283-287.

Crookston, M. C., Tilley, C. A., and Crookston, J. H. (1970). Human chimaera with seeming breakdown of immune tolerance. Lancet, 2, 1110-1112.

Gundolf, F. (1973). Anti- $A_{1} \mathrm{Le}^{\mathrm{b}}$ in serum of a person of blood group $A_{1}$ h. Vox Sanguinis, 25, 411-419.

Race, C. and Watkins, W. M. (1972). The action of blood group B gene-specified $\alpha$-galactosyltransferase from human serum and stomach mucosal extracts in group $\mathrm{O}$ and 'Bombay' $\mathrm{O}_{\mathrm{h}}$ erythrocytes. Vox Sanguinis, 23, 385-401.

Seaman, M. J., Chalmers, D. G., and Franks, D. (1968). Siedler: an antibody which reacts with $\mathrm{A}_{1} \mathrm{Le}(\mathrm{a}-\mathrm{b}+)$ red cells. Vox Sanguinis, 15, 25-30.

Swanson, J., Crookston, M. C., Yunis, E., Azar, M., Gatti, R. A., and Good, R. A. (1971). Lewis substances in a marrow-transplantation chimaera. Lancet, 1, 396.

Tilley, C. A., Crookston, M. C., Brown, B. L., and Wherrett, J. R. (1975). $A$ and $B$ and $A \mathrm{Ae}^{\mathrm{b}}$ substances in glycosphingolipid fractions of human serum. Vox Sanguinis, 28, 25-33.

Wrobel, D. M., McDonald, I., Race, C., and Watkins, W. M. (1974). 'True' genotype of chimaeric twins revealed by blood group gene products in plasma. Vox Sanguinis, 27, 395-402.

\section{A case of hypogonadotrophic} hypogonadism with anosmia (Kallmann's syndrome) in a male, with familial incidence of a small metacentric chromosome $(47, \mathrm{XY}, \mathrm{mat}$ ? +)

\section{Summary. A case of Kallmann's} syndrome in a male is reported. Besides the classical picture of hypogonadotrophic hypogonadism (demonstrated both by endocrine investigation and a testicular biopsy) with anosmia, a number of other unusual features are present including gynaecomastia, agenesis of the anterior brachial muscles, some dental abnormalities, and dyschromatopsy. The karyotype, studied on peripheral lymphocytes, shows, in the propositus as well as in his mother, the presence in all mitoses of an extra small metacentric chromosome; its derivation is uncertain.

The association of anosmia with hypogonadotrophic hypogonadism is a rare, but now wellrecognized condition, also known as Kallmann's syndrome (Kallmann et al, 1944) or olfactory-genital dysplasia (de Morsier, 1954). The condition appears to be heterogeneous, both because of the different patterns of inheritance, and also with respect to response to clomiphene. The syndrome has been described in both sexes, and, as several members of a kinship can be affected, it has been suggested that it is genetically determined. However, the mode of inheritance is still uncertain; in fact, behaviour consistent with $\mathrm{X}$-linked dominant inheritance, $\mathrm{X}$-linked recessive inheritance, and autosomal dominant inheritance have all been reported (McKusick, 1971). Santen and Paulsen (1973) reported a clinical study of six families which suggests an autosomal dominant pattern of inheritance with variability in expressivity, but the authors did not exclude a genetic heterogeneity.

Whereas most investigators report no response to short- or long-term administration of clomiphene in Kallmann's syndrome, Hamilton et al (1973) obtained a different response according to the severity of anosmia: in Type I anosmia (no response to vapours at the primary olfactory area) clomiphene was ineffective, whereas some subjects with Type II anosmia (subnormal response to vapours at the primary olfactory area; olfactory responses can be made in an attenuated manner) responded adequately to prolonged treatment. In the view of the authors, the two types of anosmia imply a more or less severe defect of the olfactory lobe; this, in turn, is associated with a different degree of 'maturation' of the hypothalamus, which could explain the positive or negative response to clomiphene. No chromosomal abnormality has so far been described in this syndrome. We therefore report a case where, in addition to the typical features of hypogonadotrophic hypogonadism with anosmia, other abnormalities and an extra small chromosome have been observed; the latter was also present in the maternal karyotype. 